\title{
Media Dissemination "The Threat of Tsunami Unleashed from the Eruption of Mount Anak Krakatau" Through Documentary Movie
}

\author{
M. Yudhi Rezaldi \\ Wahjoe Soeprihantoro
}

\author{
Information and Technology Unit, LIPI, Indonesia \\ Center for Geo-technology, LIPI, Indonesia
}

\begin{abstract}
The Eastern side of the Sunda Strait coastal line is an area which faces directly towards the source of the disaster. Mount Krakatau's explosion causes major eruptions and destructive tsunami waves back in 1883, causing severe damages to the area and a death-count reaching 30,000 people. Learning from past, it is important to convey the understanding of natural hazards to the public. Spreading knowledge of the threat needs to be done by using methods that can easily be accepted, understood and implemented by any kind of communities. This preliminary research compels that the general population does not have sufficient understanding on this natural disaster. They are also oblivious to what procedure should be taken when such a tragedy occur. The research also illustrates that the audiovisual media is the most appropriate and favored method of gaining knowledge by the community. The media is constituted of multiple segments of 3D animations, digital computer animations, and short field-filmed clips, which are then assembled into one single documentary presenting both a virtual-reconstruction of the event whilst giving a variety of information concerning the subject. The content of the documentary will provide information about the Krakatau tsunami, the current condition of Mount Anak Krakatau, the signs leading to a volcanic eruption and a tsunami, and the necessary steps that they will have to follow in response to such threat. This documentary movie will hopefully become an educational tool to expand people's knowledge and awareness at the event of an eruption and a tsunami.
\end{abstract}

Keywords: Anak Krakatau Mount, tsunami, media dissemination, documentary, animation

\section{Introduction}

Being localized inside the geological phenomenon known as "the ring of fire", Indonesian islands are formed and molded by years of volcanic activities that are partially still active (figure: 1, Map of Indonesia with dots symbolizing volcanos). The recurring and abundance of volcanic activities in the region has created a history of various kinds of eruptions, all with their respective level of destruction and death.

The Sunda Strait has witnessed many of Mount Krakatau's eruptions, the largest one being the eruption of 1883 
which had caused a huge amount of destruction in the area (Hantoro, 2006, Simkin and Fiske, 1983) not only due to tidal waves the eruption produced, but also by the ejection of volcanic debris into the atmosphere and the earthquakes following the explosion. The intensity of the tsunami is shown by the presence of large chunks of limestone coral reefs in places far from the place of origin (Hantoro 1992, Latief et al. 2002). Also, the presence of a ship which was anchored at Telukbetung had been pushed away 2.5 $\mathrm{km}$ into the upstream of Kuripan River (Simkin \& Fiske, 1983). Some markings of the tsunami are also in form of sediment crusts of coral reefs which were found far away from the shoreline of Anyer (Latief et al., 2002) and in the bay area of Lampung (Hantoro, 1992). The tsunami has taken 36,000 casualties, a very large number when taking into consideration the year of occurence.

The Sunda Strait region has been an important location even so today, it serves as a gate for sailing activities and a passage way to cross from the island of Sumatra to Java (Hantoro, 2006). Its status and its role has become even more important following the huge development leap in the end of $20^{\text {th }}$ century, with an improvement of the quality of access to the surrounding area and the emergence of many economic activities such as industrial activities (chemical, metallurgy, energy, etc), transportation (Merak, Bakauheni, Panjang, Tarahan, etc), fishery (Padang Cermin, etc) and a military base (Teluk Ratai). The geographical location of the area is very strategic as it stands as the gate of sailing from the Indian Ocean and its close proximity to the center of government of the country (Jakarta) and province (Tanjung Karang) (Figure 2). Surrounding this body of water, there are also conservation sites and a national park, which also is vital but threatened by natural disasters. Aside from the importance of its status and its role, potential disaster also resides in the area in the form of a volcanic eruption and tsunamis caused by the eruption of Mount Anak Krakatau. Possibly, Mount Krakatau's eruption had also previously occured far in the past which is suspected as being the reason for the migration of archaic humans (Hantoro 2003a). 
Figure 1.1. : Landsat 7 Image of Banten, Sunda Strait and Mount Krakatau

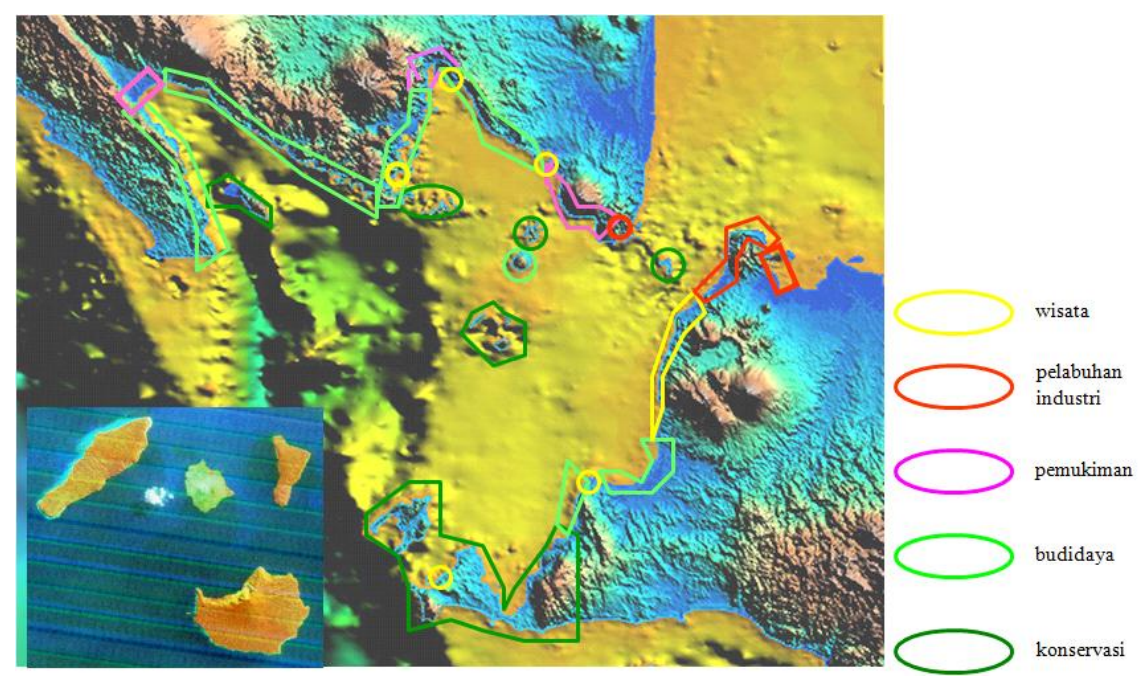

Note: Presenting zones ranging from ports and industries in Banten-Merak and Cilegon, residential and touristic areas from Anyer to Carita, cultivation sites from Labuan to Tanjung Lesung, wells and conservation areas in Ujung Kulon and Panaitan.

When looking back at the danger of the Krakatau eruption and the environmental development in Sunda Strait, the inhabitants residing in the strait-coastal area has to be aware of the tragedy that had occured in the past and have to be taught knowledge on how they, along with the government, should react in facing future catastrophies. One of the most important tasks that needs to be done is to give explanations, based on research results and analysis, concerning the Krakatau Volcano eruptions and the possible catastrophic threats that might happen in the future. Other than that, people need to understand the signs leading to a possible disaster as well as what to do during such a life-threatening situation, such as, what kind of warning signal has to be implemented, how to manage the people in saving their lives and belongings, what kind of equipment and shelter must be provided and prepared during the rescue mission. As a mitigation, in the situation when an eruption have resulted in another threat such as the emergence of a tsunami wave, the community has to know what form of protection is needed to minimize the threat of the wave.

This research is aimed at observing the information dissemination model with the goal of preparing the people for future threats of Anak Krakatau Mountain and how it enables the people, along with the government, building facilities that is qualified to reduce the hazardous impact of volcanic eruptions and tsunamis. The socialization and dissemination of this knowledge are delivered in the form of a documentary movie which explains the natural phenomenon of eruptions and the steps that must be followed when such a catastrophy occurs. Besides, the use of social media is also explored.

One of the problems found during this research is finding the right method for calculating and evaluating the level of understanding of the population living around the location of Anak Krakatau Mountain concerning how well they are prepared to face a tsunami. This research will be limited on determining the most 
appropriate dissemination media to deliver education and knowledge about tsunamis in the Carita coastal area in Banten Province. The information consists of records on the past tsunami tragedy, the current condition of the source of disaster, the signs leading to the disaster and the required steps to be followed during the catastrophy.

\section{Methodology}

This research began with a descriptive search that was conducted on March 2014 in the Carita coastal area by spreading questionnaires and interviewing some sources. With random sampling technique, 100 questionnaires were circulated which was divided into three groups: students, workers and the general public. The results were analyzed using the anova analytic method permitting us to calculate the difference of opinions between the respondents.

Interviews were also conducted to sources who were directly affiliated to the subject, such as researchers in the field of disasters from the Research Center for Geotechnology-LIPI, the guarding officer of Anak Krakatau volcano observation from Geological Agency of the Ministry of Energy and Mineral Resources, the village head of Pasauran Carita and Head of the Regional Disaster Management Agency of Pandeglang area.

During the shooting process in the field, there were few difficulties when taking the image of Anak Krakatau mountain, mainly the difficulty in obtaining an authorization from the guards at the location. Anak Krakatau mountain is located in high seas so a speedboat was needed to get to the location, and it was hard filming on a speedboat concidering the shakiness making the shot unsteady.

During another part of the shooting, there were also good moments, such as: the company of a Geotechnology LIPI researcher who previously had done research on tsunamis, easing and helping find the location that shows traces of the past tsunami. The audience were very cooperative in facilitating the shooting process of their interview and also provided accurate information.

During other production processes, namely during animation production, there were difficulties due to limited capabilities of the computers, thus making the process of rendering the animation longer.

\section{Discussion}

This section consists of the analysis taken from the result of the questionnaire and the interviews, it presents a parameter of the level of understanding of the population concerning the disasters, which dissemination medium is more favored, and which kind of dissemination method has been used in the region.

The result of the interviews varies considerably. Because the interviewees were given a variety of questions and had the freedom to choose any answer that they would like, it is without saying that the interviewees had different opinions from one another regarding the subject which affected the results of the questionnaire. Age, the level of education and the environment also have to be noted as factors that affects people's decisions. 
Table 1. Questionnaire results concerning the level of understanding of people living in Carita Beach

\begin{tabular}{|c|c|c|c|c|}
\hline Parameter & Student & $\begin{array}{c}\text { Workerl } \\
\text { Employer }\end{array}$ & Public & Total \\
\hline Knowledge of pas tevents & 35 & 35 & 25 & $95 \%$ \\
\hline Knowledge of tsunamis. & 35 & 35 & 30 & $100 \%$ \\
\hline $\begin{array}{c}\text { Knowledge of the signs leading } \\
\text { to a tsunami. }\end{array}$ & 23 & 19 & 14 & $56 \%$ \\
\hline $\begin{array}{c}\text { Knowledge of the steps that must } \\
\text { be performed during a tsunami }\end{array}$ & 23 & 21 & 11 & $55 \%$ \\
\hline $\begin{array}{c}\text { Have seen/heard/read media } \\
\text { disseminations about tsunamis }\end{array}$ & 24 & 26 & 18 & $68 \%$ \\
\hline
\end{tabular}

From the above table, it can be observed that:

- Most respondents already know that a tsunami had happened in the area in the past: $95 \%$ of the population.

- The amoint of people whom have knowledge of what a tsunami is: $100 \%$ of the population

- The amount of people whom understood the signs marking an impending tsunami was not sufficent and unsatisfying:

- $56 \%$ of the population.

- Only $55 \%$ of the interviewed people knew which steps has to be followed during a tsunami.

- $68 \%$ of the interviewees knew about the dissemination medium, which can be concluded as being satisfying but still not being the most appropriate.

Table 2. Dissemination mediums that are most preferred by the Carita beach community

\begin{tabular}{|ll|c|c|c|c|}
\hline \multicolumn{2}{|c|}{ Dissemination medium } & Students & Workers & Public & Total \\
\hline - & Radio & 17 & 10 & 4 & $21 \%$ \\
\hline - & Film (DVD) & 15 & 13 & 17 & $57 \%$ \\
\hline - & Poster & 3 & 3 & 5 & $11 \%$ \\
\hline - & Television & 3 & 4 & 2 & $7 \%$ \\
\hline - & Simulation & 1 & 3 & 0 & $4 \%$ \\
\hline
\end{tabular}

From the research, the results have shown that:

- The most prefered method of dissemination is through movies (DVD) with a percentage of $57 \%$.

- The second most prefered method is through the radio with a percentage of $21 \%$.

- The least liked mediums are posters at $11 \%$, television at $7 \%$ and simulations at $4 \%$. 
Table 3. Result from the interviews concerning dissemination medium

\begin{tabular}{|c|c|c|}
\hline Sources & Declarations & Conclusions \\
village & $\begin{array}{c}\text { The overwhelimg amount of information } \\
\text { concerning the hazard of a tsunami hitting Carita } \\
\text { beach had caused a decline in touristic activities, } \\
\text { which by itself affected the inhabitants' economy. }\end{array}$ & $\begin{array}{c}\text { The dissemination was } \\
\text { used inappropriately, it } \\
\text { had affected the } \\
\text { psychology of tourists. }\end{array}$ \\
\hline $\begin{array}{c}\text { Teacher } \\
\text { from SMK 3 } \\
\text { Pandeglang }\end{array}$ & $\begin{array}{c}\text { Some simulations have been organized in the } \\
\text { research location, which required the people to } \\
\text { go towards the hill in hope for shelter, but one } \\
\text { person had been bitten by a venomous snake } \\
\text { and died a few hours later. }\end{array}$ & $\begin{array}{c}\text { Inappropriately used, } \\
\text { unsafe, there are many } \\
\text { wild animals and steep } \\
\text { sleeks which might cause } \\
\text { death when people are } \\
\text { not careful. }\end{array}$ \\
\hline
\end{tabular}

Two important information can be taken from result of the interview:

- The dissemination of information on a large scale outside the research site (national scope) brings a negative impact to the economy, by knowing that such a threat exists, potential tourists are pushed away from visiting the region.

- Dissemination through simulation is unsafe, this can be proven by the death of an inhabitant who was bitten by a venomous snake whilst running towards the shelter.
- Based on those two informations, it can be concluded that information should only be given to the people who live in hazardeous areas and simulations should not be performed without the proper planning and equipments because of safety concerns.

Besides the three methods above, a comparison between other dissemination mediums having a potential to be used had been done and the results can be seen in the table below:

Tabel 4. Comparison of some dissemination mediums

\begin{tabular}{|c|l|}
\hline Media type & $\begin{array}{l}\text { Written media } \\
\text { (Journal, poster, leaflet, booklet, company profile and policy briefing) }\end{array}$ \\
\hline Advantage & $\begin{array}{l}\text { Not durable, easily get wet/ripped, people will get bored when receiving } \\
\text { too many information }\end{array}$ \\
\hline Disadvantage & $\begin{array}{l}\text { Not durable, easily get wet/ripped, people will get bored when receiving } \\
\text { too many information }\end{array}$ \\
\hline Analysis & $\begin{array}{l}\text { Not recommended, because it will easily get damaged and is the contrary } \\
\text { of our needs }\end{array}$ \\
\hline Media type & $\begin{array}{l}\text { Electronic media } \\
\text { (documentary, radio, television, website, interactive cd ) }\end{array}$ \\
\hline Advantage & $\begin{array}{l}\text { Very informative because it can show images and sounds at once, making } \\
\text { it visually appealing so that people will get pleased when watching it. }\end{array}$ \\
\hline
\end{tabular}




\begin{tabular}{|c|c|}
\hline Disadvantage & $\begin{array}{l}\text { Needs specific tools such as: radio, television, computer, dvd player, } \\
\text { network, and electricity. }\end{array}$ \\
\hline Analysis & $\begin{array}{l}\text { Television and radio are not recommended because during a test in } \\
\text { another research, the overwhelming amount of information had made the } \\
\text { hazardous area unattractive to tourists } \\
\text { CD is not a recommended medium, not all houses on the research site } \\
\text { have the required tool to read it. } \\
\text { Documentaries are highly recommended, because it can be distributed } \\
\text { directly to the audience who lived in the disaster area so that the audience } \\
\text { can be monitored, and almost all houses have televisions and dvd players. }\end{array}$ \\
\hline Media type & $\begin{array}{l}\text { Scientific Meetings } \\
\text { (seminar, workshop, technology exhibitions and discussion group, } \\
\text { counseling, technical training ) }\end{array}$ \\
\hline Advantage & $\begin{array}{l}\text { A direct two-way communication can occur directly between the } \\
\text { communicator and the receiver, other methods of dissemination can also } \\
\text { used during the meeting. }\end{array}$ \\
\hline Disadvantage & $\begin{array}{l}\text { Requiring a special place / room for the meeting, need to manage the } \\
\text { schedule to gather the sources and the audiences. }\end{array}$ \\
\hline Analysis & $\begin{array}{l}\text { Not recommended, because this media can only be done once, meanwhile } \\
\text { we could never know when the tsunami might occur. The audience, the } \\
\text { inhabitants, might not remember correctly if they are reminded only once. }\end{array}$ \\
\hline Media type & Exhibition \\
\hline Advantage & Very informative to display original products that needs to be presented. \\
\hline Disadvantage & $\begin{array}{l}\text { There are difficulties when a large product needs to be displayed, for } \\
\text { example if the location of the exhibition is far away, or if additional tools } \\
\text { such as tables, cases etc are also needed to display the product. }\end{array}$ \\
\hline Analysis & $\begin{array}{l}\text { Not recommended, because there is no need to exhibit a product in for our } \\
\text { research }\end{array}$ \\
\hline Media type & Plot demonstration media / Simulation \\
\hline Advantage & $\begin{array}{l}\text { The audience can directly practice and understand the necessary steps } \\
\text { when facing the disaster. }\end{array}$ \\
\hline Disadvantage & $\begin{array}{l}\text { Must be done by experts in the field whom knows the area very well. If } \\
\text { not, there could be a high risk of injury. }\end{array}$ \\
\hline Analysis & $\begin{array}{l}\text { Not recommended, because this type of medium had been done in the } \\
\text { research location and someone died in the shelter because of a venomous } \\
\text { snake. }\end{array}$ \\
\hline
\end{tabular}

The comparison of various dissemination media commonly used in conveying information results that documentary movie is the most preferred media.
The table below shows the status and information concerning past studies done by researches who treats the subject of information dissemination: 
Table 5. Assessment of previous studies

\begin{tabular}{|c|c|}
\hline Title & $\begin{array}{c}\text { Study on the Effectiveness of the Information Dissemination } \\
\text { Concerning the Mitigation of the Risk of Disaster in a Disaster- } \\
\text { prone Region (Studi Efektifitas Diseminasi Informasi Pengurangan } \\
\text { Resiko Bencana Didaerah Rawan Bencana) }\end{array}$ \\
\hline Researcher & Arifianto.S. et al. \\
\hline Media used & Sugged television as the most dominant medium \\
\hline $\begin{array}{l}\text { The positive } \\
\text { impact/excess }\end{array}$ & $\begin{array}{l}\text { The spread range of the information is much wider and can be } \\
\text { delivered rapidly to reach many audiences in multiple areas, locally } \\
\text { or abroad. }\end{array}$ \\
\hline $\begin{array}{l}\text { The negative } \\
\text { impact/shortage }\end{array}$ & $\begin{array}{l}\text { The delivered message can not be sent solely to a specific target } \\
\text { population, therefore risking to cause panic amongst the people }\end{array}$ \\
\hline Title & $\begin{array}{l}\text { Disaster Literacy among Society in a Disaster-origin Region: Case } \\
\text { Study of the Marketing of Social Readiness towards Disaster in } \\
\text { Padang, West Sumatera (Literasi Bencana Pada Masyarakat Rawan } \\
\text { Bencana: Studi Kasus Pemasaran Sosial Siaga Bencana di Padang, } \\
\text { Sumatera Barat) }\end{array}$ \\
\hline Researcher & Dewi Sad Tanti, D.S. \\
\hline Media used & Direct meeting in the form of an evacuation simulation. \\
\hline $\begin{array}{l}\text { The positive } \\
\text { impact/excess }\end{array}$ & $\begin{array}{l}\text { People's knowledge regarding the disaster have been enriched with } \\
\text { important information and have become more aware. }\end{array}$ \\
\hline $\begin{array}{l}\text { The negative } \\
\text { impact/shortage }\end{array}$ & $\begin{array}{l}\text { During a real disastrous event, it will not be a surprise if the } \\
\text { evacuation will not be as fast as when it was simulated. } \\
\text { Based on past experiences, when a tsunami occurs, many people will } \\
\text { be in the situation where they are driving their private vehicles } \\
\text { therefore causing a longer evacuation process. Traffic jams and the } \\
\text { presence of narrow streets will cause a bottleneck and make it harder } \\
\text { for people to travel fastly. }\end{array}$ \\
\hline Title & $\begin{array}{c}\text { Disaster Information and Local Culture: Case Study Post-Disaster } \\
\text { Reconstruction, Bukit Duri District Flood, South Jakarta (Informasi } \\
\text { Bencana dan Budaya Lokal: Kasus Penanggulangan Banjir di } \\
\text { Kelurahan Bukit Duri Jakarta Selatan) }\end{array}$ \\
\hline Researcher & Arifianto, S. and Mohan Rifqo Virhani. \\
\hline Media used & Television \\
\hline $\begin{array}{c}\text { The positive } \\
\text { impact/excess }\end{array}$ & Wider spread on delivering information \\
\hline $\begin{array}{l}\text { The negative } \\
\text { impact/shortage }\end{array}$ & $\begin{array}{l}\text { Mostly during the flood, people in disaster area will not be able to } \\
\text { watch any television, due to the lack of power during the flood. }\end{array}$ \\
\hline Title & $\begin{array}{c}\text { Independent Evacuation for the Coastal Inhabitants from Tsunami } \\
\text { Threat: Pre-Tsunami (Evakuasi Mandiri Bagi Masyarakat Pantai } \\
\text { Terhadap Bahaya Tsunami: Pra-tsunami) }\end{array}$ \\
\hline Researcher & Dyah Rachmawati, et al. \\
\hline Media used & Teaching Module \\
\hline
\end{tabular}




\begin{tabular}{|c|l|}
\hline $\begin{array}{c}\text { The positive } \\
\text { impact/excess }\end{array}$ & $\begin{array}{l}\text { The thaught material can be more vast, more clear, more detaild and } \\
\text { can be read multiple times, so that the chance to remember is bigger. }\end{array}$ \\
\hline $\begin{array}{c}\text { The negative } \\
\text { impact/shortage }\end{array}$ & $\begin{array}{l}\text { When the source module consists of many pages, the effort needed to } \\
\text { completely understand the subject can make people go lazy and not } \\
\text { read it. }\end{array}$ \\
\hline Title & $\begin{array}{l}\text { Dissemination of A Tsunami Threat Through a Sign System in the } \\
\text { Carita Coastal Area (Diseminasi Ancaman Tsunami Melalui Sign } \\
\text { System Untuk Kawasan Pantai Carita) }\end{array}$ \\
\hline Researcher & Muhammad Yudhi Rezaldi \\
\hline Media used & Sign System \\
\hline $\begin{array}{c}\text { The positive } \\
\text { impact/excess }\end{array}$ & $\begin{array}{l}\text { People can know towards which direction they need to go when the } \\
\text { disaster occurs. }\end{array}$ \\
\hline $\begin{array}{c}\text { The negative } \\
\text { impact/shortage }\end{array}$ & $\begin{array}{l}\text { Specific tools must be provided to re-paint the module, the medium } \\
\text { has to be repaired annually }\end{array}$ \\
\hline
\end{tabular}

From the analysis of the methods presented above, we can conclude that people's awareness of tsunamis is evident, but most people in the tourist area around Carita beach do not understand the signs indicating the coming of a tsunami and have no knowledge on what to do during the disaster. Therefore a proper dissemination media to provide such information are highly necessary.

Based on the results of this analysis, we produced a media that combined documentary movie and an animated movie, namely:

- The of documentary will provide the viewers with a reconstruction sequence along with scientific explainations, which will provide an overview of the events that had occurred. It gives some information on the current situation of the subject and show predictions or more precisely teach how to predict future threats (Fauzan, 2013).

- The animation sequence used in the documentary combines 3D animation and $2 \mathrm{D}$ animation, with the type of computer-made/digital three dimensional animation done with a simplistic style. (Djalle, Purwantoro, Dasmana, 2007)
Theoretically, the audio-visual medium, in our case in the form of a documentary, is considered as the most acceptable method for delivering the message. According to the research institute of computer technology research and development (CTR), people only remember $20 \%$ of what they see and $30 \%$ of what they hear, but one can capture up to $50 \%$ if they see and hear the information simultaneously (Fred, 2001)

\section{Movie Making Process}

The process of making the movie is divided into three stages that are conducted as follow:

\section{Pre-Production}

In this phase, we collected data from various sources concerning the subject (Mount Anak Krakatau) as well as information about past events, we researched the current condition of Anak Krakatau from a variety of published sources, and seeked information from experts in the field of natural disasters.

The retrieved data have then been used to make a storyline and story board which served as guidelines during film 
production, it was then followed by effects.

recording the narrations and sound

Figure 2. The storyline of the documentary reporting the possible tsunami threat caused by the eruption of Mount Anak Krakatau

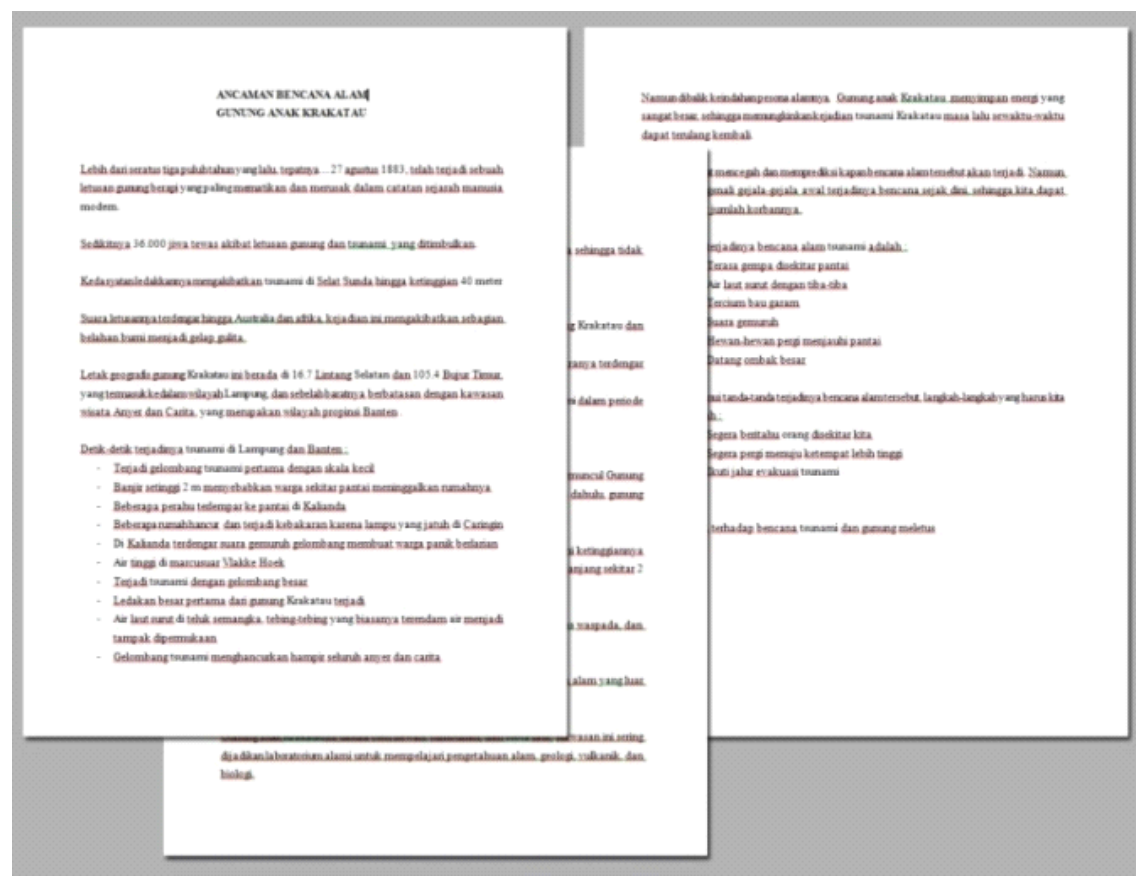

Figure 3. The storyboard of the documentary reporting the possible tsunami threat caused by the eruption of Mount Anak Krakatau

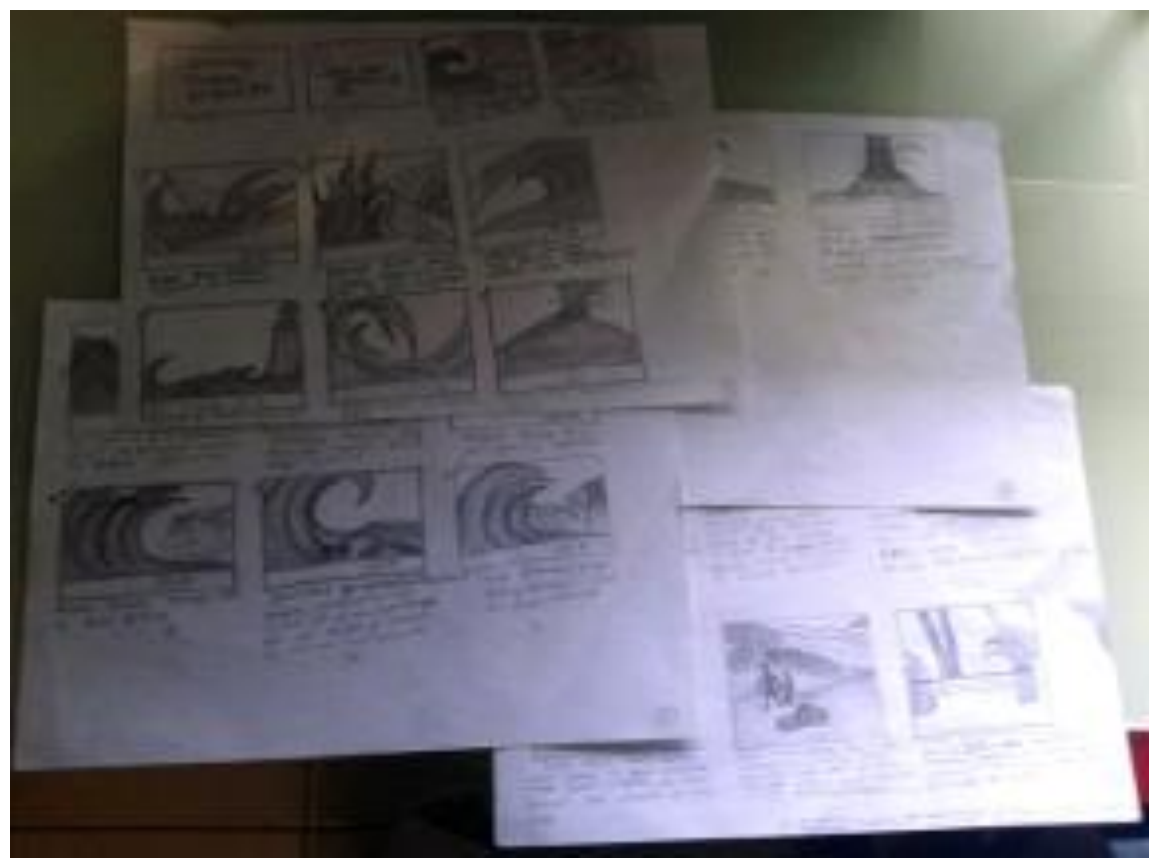


Production

In the production phase, we collected visual data by filming at the research sites around Carita beach, in the location of Anak Krakatau, and in some areas in the province of Lampung. Then, the process had to be done in a multimedia laboratoy and we needed to make two and three dimensional animations using the software 3DS Max and Adobe After Effects. Following that, the footages needed to be combined through editing, the dubbings needed to be made and the sound effects were inserted using the software Final Cut Pro.

Figure 4. The process of creating an animation in 3DS Max

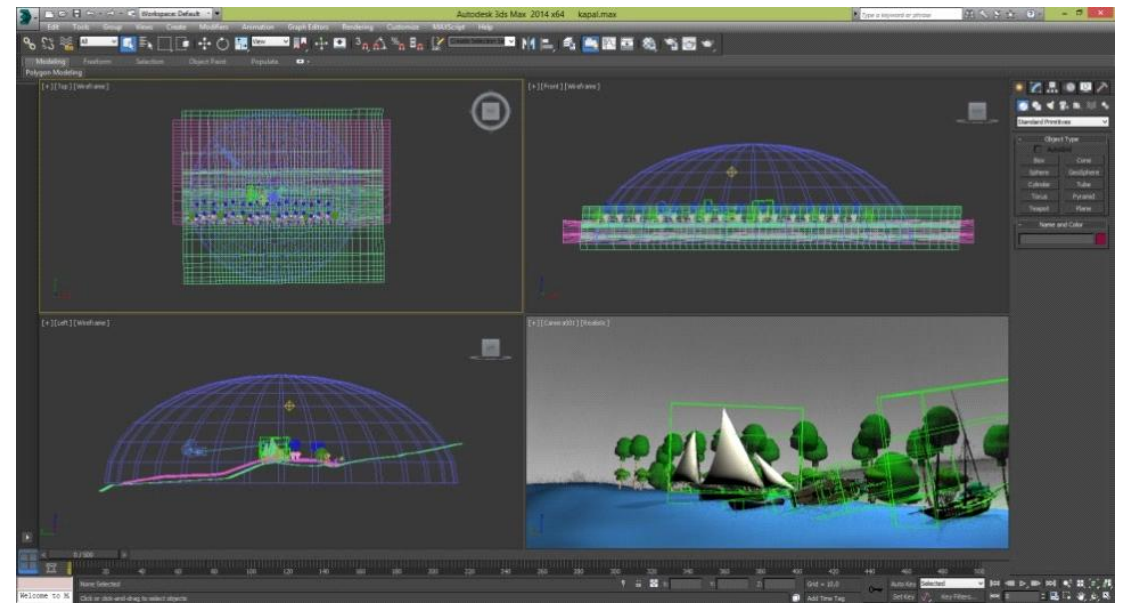

Figure 5. The process of creating an animation in Adobe After Effects.

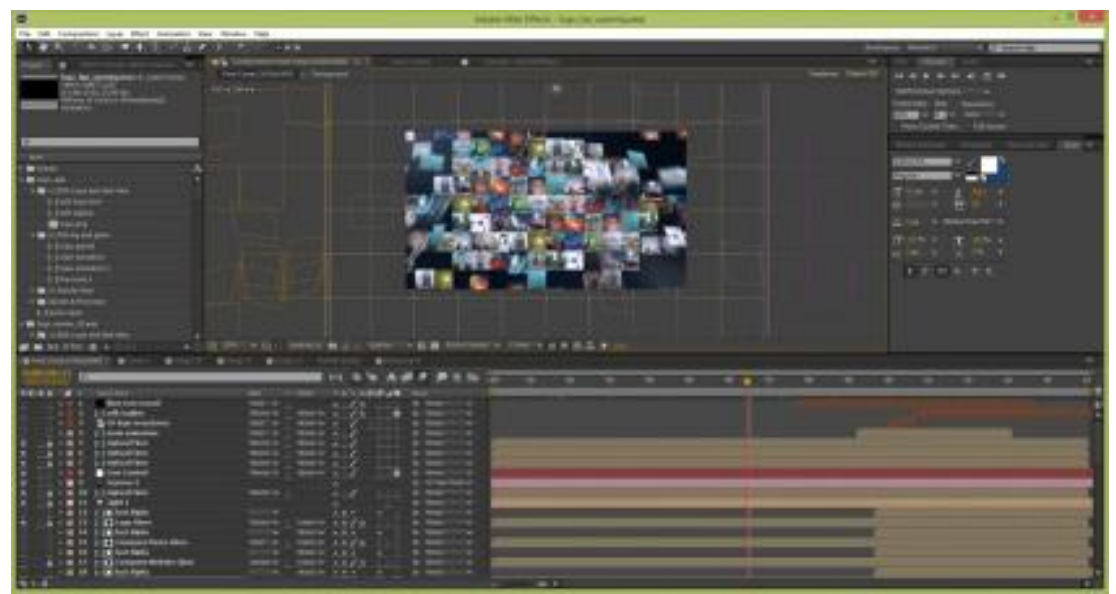

\section{Post Production}

The post-production process is the final process in the making of the film. In this process, the procedure was to first edit, compose and combine all audio and visual data, so that all of these elements will be combined into one single video file through the rendering process, using 
Final Cut Pro, and then proceed using a software to turn the final product into a readable DVD file through a compressor software. And the last is to make the DVD's case design using Adobe Photoshop.

Figure 6. The process of editing using final cut pro

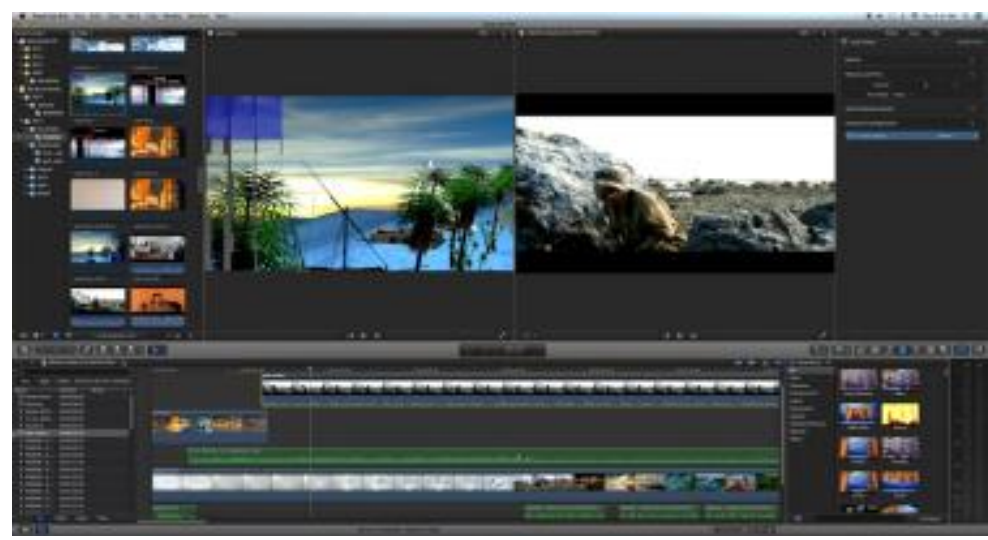

Figure 7. The process of burning a DVD using a compressor software

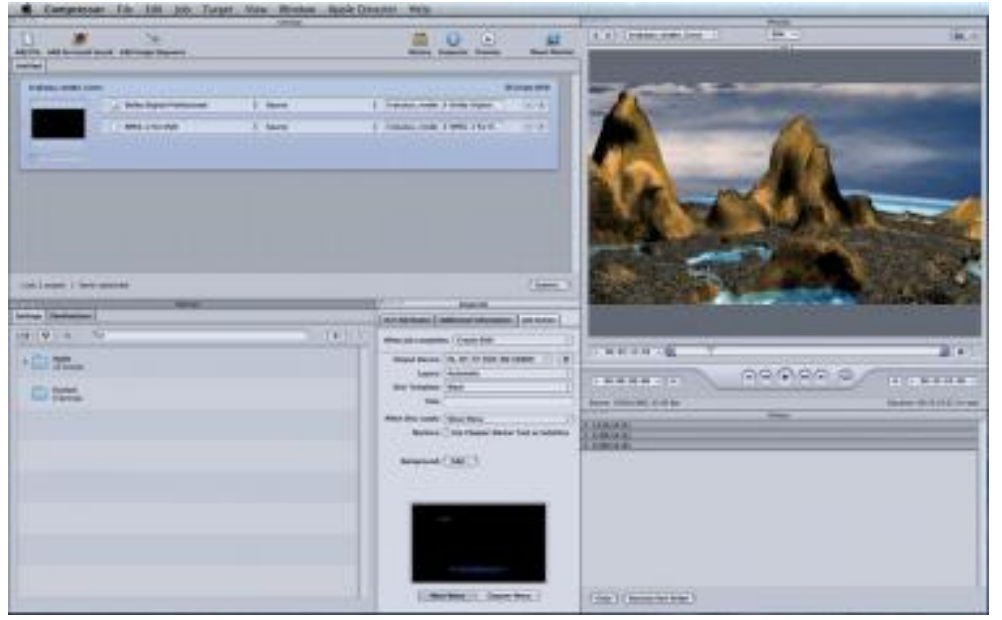

\section{Media Dissemination}

The chosen method of disseminating the documentary was to distribute the DVDs/VCDs to the disaster affected inhabitants or to various stakeholders including structural and functional officials in UPT. Center for Information Technology - LIPI, researchers in the field of natural disasters. Geotechnology Research Center - LIPI, the National Library and Archives of Banten Province, Banten Tv, Pasauran Village Offices, the Center of Volcanology and Geological Hazard Mitigation, Post observers of Mount Anak Krakatau, PT. Krakatau Tour Indonesia, SMAN 3 
Pandeglang, Regional Disaster Management Agency, the World Wildlife Reading House Cilegon. The movie, entitled "Tsunami Threat Due to the Eruption of Mount Anak Krakatau" can also be seen on website of BIT - LIPI. ${ }^{1}$

\section{Conclusion}

By looking at background of past tsunami events, it is necessary to make an effective dissemination medium in order to inform similar threat of natural disaster that can occur at any time, hoping that people will have knowledge on the devastating disastrous events of the past, and it is considered necessary to know the signs leading to a tsunami, what procedure should be taken to save lives, which in turn can minimize the loss of life.

To know what type of dissemination media is the most appropriate to be used to inform this problem, researchers distributed a number of questionnaires and had done many interviews. The result is that the respondents has a good understanding about tsunamis. However, there are many people who do not understand the signs of an impending tsunami and they also do not know very well steps to do if one day the tsunami occurs.

The tragic incident of a villager's death caused from a snake bite, at the time of the simulation, has become a very strong reason for the need of a secure media to convey information, in which requiring a media that does not contain the above risk and other risks such as panic and falling when running.

http://multimedia.bit.lipi.go.id/index.php?opti on=com hwdvideoshare\&task=viewvideo\&Ite mid=\&video $\mathrm{id}=161$
Due to the spread of previous information in a large scale outside the research site (national scope) through various medias, brought a negative impact on the economy, since many people were informed of how hazardeous the location is to tsunamis, people will be afraid to visit the location, therefore losing potential tourists. The second reason is the belief that the most appropriate media will the audio-visual media.

The documentary will be constitued of two sequences: a reconstruction sequence and a scientific explaination, where it will provide a reconstruction of past events, the current condition of mount Anak Krakatau, and what kind of prediction will come. This documentary will have an animated sequence which combines $3 \mathrm{D}$ animation and $2 \mathrm{D}$ animation, the animation type is three dimensional computer-animation / digital, with a simple style.

The documentary is targeted towards the people who lives in coastal tourism areas of Carita beach which consists of of workers, students, and the general public. This new dissemination media is expected to broaden the knowledge of the people in the coastal areas in Carita beach, whilst raising public understanding, caringness and awareness to the tsunami disaster.

\section{Suggestion}

The dissemination of information to the public regarding this disaster should be done properly and carefully so as to not cause panic and fear, because it can affect the psychological state and the safety of the community.

Since Carita beach is a tourism 
destination, organizing a massive dissemination of information stating that the area is hazardous and dengerous can make tourists be unappealed to visit the

\section{Acknowledgements}

The authors profusely thank to all parties and the cooperation of those who have helped us complete this research, including:

1. Indonesian Institute of Sciences, which has financed this research.

2. Mr. Evandri M. Eng. Sc., as Head of Technical Management Unit for Technology Information - LIPI.

3. Gonang May Prime Nugraha, as Head of Unit PSIT. in Technical Management Unit for Technology Information - LIPI.

4. All Staff in UPT. Technology Information - LIPI, which has supported the course of this study.

5. Rival, from Krakatau Tour Indonesia, which have been guiding our trips during field study.

6. Marlino Deni, from the Center for Volcanology and Geological

\section{References}

Arifianto.S, et. al. 2009. Studi Efektifitas

Diseminasi Informasi Pengurangan

Resiko Bencana Didaerah Rawan

Bencana.

Departermen

Komunikasi dan Informatika.

Puslitbang APTEL SKDI. Badan

Penelitian dan Pengembangan SDM

Awaludin Soheh A, Kanti Wilujeng Walujo KW. 2014. Efektifitas Tabloid Komunika Sebagai Media Diseminasi Informasi Bagi Pegawai Puslitbang Postel dan Puslitbang place, thus affecting the economic growth the people living in Carita beach.

Hazard Mitigation.

7. Mr. Agus Japar, as the village chief of Pasauran which was the location where we had distributed all of our questionnaires.

8. Mr. AIP Somahmud, as the head of BPBDs Pandeglang on the information provided at the time of the interview.

9. Local Government of Pandeglang, for all the permissions that have been granted so that we can perform data collection and research location shooting.

10. Ranger, the Guard of Mount Anak Krakatau natural reserve, for the opportunity so that we were authorized to take pictures at Anak Krakatau mountain.

11. Other parties who have supported the completion of this study, whose names could not all be enumerated.

Aptel SKDI Badan Litbang SDM DEPKOMINFO. Universitas Esa Unggul.

http://www.esaunggul.ac.id

Djalle ZG, Purwantoro E, Dasmana D. 2007. " The Making of $3 d$ Animation Movie Using 3D Studio Max". Informatika. Bandung

Fauzan, A.AS. 2013. Penulisan Naskah Non Berita Jenis Program Dokumenter. Modul Perkuliahan. Universitas Mercu Buana. Jakarta Fatkhurrokhim N, Ramadhani N. 2012. Perancangan Film Dokumenter Wayang Topeng Malang. Jurnal 
Sains dan Seni Pomits Vol.1, No.2, (2012) 2301-928X

Fred T, Hofstetter. 2001. Multimedia Literacy. New York. McGraw-Hill Irwin.

F Sani Asrul. 2007. Penulisan naskah Non Berita Jenis Program Dokumenter. Bandung. Fakultas Ilmu Komunikasi Unikom.

Hapsari DA, Urbani YH. 2014. Pembuatan Film Dokumenter "Wanita Tangguh Dengan Kamera DSLR Berbasis Multimedia". Indonesian Journal on Networking and Security Volume 3 No 1. http://ijns.org

Hah Jee Eui, Schmutz P, at all. 2008. Cinematographic Techniques in Architectural Animations and Their Effects On Viewers Judgment. International Journal Of Design. www.ijdesign.org.

Hantoro Wahyoe, S. 1992 : "Etude des terrasses récifales quaternaires soulevées entre le détroit de la Sonde et l'le de Timor, Indonésie Mouvements Verticaux de la Croûte terrestre et variations $\mathrm{du}$ niveau de la mer" . Ph.D Thesis Univ. d'Aix Marseille II. France. Vol I 761p et Vol. II 225p. Published.

Hantoro, Wahyoe, S, et al. (2006) : Tsunami Volkanik Krakatau "Studi Kronologi dan Upaya Mitigasi di Selat Sunda". Laporan Penelitian. Bandung. Puslit Geoteknologi LIPI.

Jamal E, dkk. 2008. Proses Diseminasi Pengelolaan Tanaman dan Sumberdaya Terpadu (PTT) Padi. Analisis Kebijakan Pertanian. Volume $6 \mathrm{No}: 3$

Latief, H., Nanang T. Puspito, Imamura. 2002 : Tsunami Catalog and Zoning in Indonesia, Journal of Natural Disaster, Japan.
Lindstrom, dalam Tisna Kuswara. 2002. di Multimedia. Jakarta. Unv.Tarumanagara.

Nugroho Fajar.2007.. $\quad$ Yogyakarta. Indonesia Cerdas.

Rachmawati Dyah, et. al. 2011. Evakuasi mandiri Bagi Masyarakat Pantai Terhadap Bahaya Tsunami (Pra Tsunami). Pusat Penelitian Oseanografi. LIPI Press. Lembaga Ilmu Pengetahuan Indonesi.

Rezaldi M. Yudhi. 2013. Diseminasi Ancaman Tsunami Melalui Sign System Untuk Kawasan Pantai Carita. Tesis. Institut Teknologi Bandung.

Rogers, E.M. 1983. Diffusion of Innovations. Third Edition, The Free Press, New York

S. Arifianto, Virhani Mohan Rifqo. 2009. Informasi Bencana dan Budaya Lokal (Kasus Penanggulangan Banjir di Kelurahan Bukit Duri Jakarta Selatan). Hasil Penelitian Puslitbang Aptel SKDI Balitbang SDM, hal. 1-30. Jakarta. Depkominfo.

Simkin, Tom and Fiske, Richard S. 1983, Krakatau 1883 Eruption and its effects, Smithsonian Institution Press, Washington, D.C.

Tanti, Dewi, Sad,D.S. 2010. Literasi Bencana Pada Masyarakat Rawan Bencana (Studi Kasus Pemasaran Sosial Siaga Bencana di Padang, Sumatera Barat). Universitas Mercu Buana. Program Pasca Sarjana. Prodi Magister Ilmu Komunikasi.

Yoganingrum A, Maryati I, Yudhi Rezaldi M. 2012. Kebutuhan Dan Media Informasi Pengelolaan Air Tawar Masyarakat Di Kepulauan Seribu. Jurnal IPTEK-KOM, Vol. 14, No. 2, Desember 2012 (151164) 